\title{
Agency Theory Explanations of Self-Serving Sales Forecast Inaccuracies
}

\author{
Samuel Y. Todd ${ }^{1}$, Tamara A. Crook ${ }^{2} \&$ Tony Lachowetz $^{3}$ \\ ${ }^{1}$ Sport Management, Georgia Southern University, Statesboro, GA 30460-8077, USA \\ ${ }^{2}$ College of Business Administration, The University of Tennessee, Stokely Management Center, Knoxville, \\ Tennessee 37996, USA \\ ${ }^{3}$ Mark H. McCormack Department of Sport Management, Isenberg School of Management, University of \\ Massachusetts, Amherst, MA 01003, USA \\ Correspondence: Samuel Y. Todd, Sport Management, Georgia Southern University, Statesboro, GA 30460-8077, \\ USA. Tel: 1-912-478-5054. E-mail: sytodd@georgiasouthern.edu
}

Received: March 1, 2013

Accepted: March 26, 2013

Online Published: April 23, 2013

doi:10.5430/bmr.v2n2p13

URL: http://dx.doi.org/10.5430/bmr.v2n2p13

\begin{abstract}
The purpose of this paper is to develop and present a conceptual model that identifies factors contributing to accuracy in sales forecasts using agency theory's tenets. Drawing upon these tenets, a model is developed that identifies the incentives that encourage sales people to provide accurate versus inaccurate sales forecasts. Six research propositions are developed, practical implications of the model for compensation programs are discussed, and specific recommendations for future empirical work are identified. The model can guide managers on how to develop a more effective compensation system.
\end{abstract}

Keywords: Sales forecasting, Managerial efficiency, Agency theory, Excess inventories

\section{Introduction}

Both managers and front-line employees alike would agree that workplace behaviors are usually predetermined by how one is evaluated and measured. Indeed, one of the many clichés that has emerged in the corporate world is "show me how I'm measured and I'll show you how I act." This paper draws attention to a dysfunctional impact of this cliché by investigating how sales compensation systems can lead to lower firm performance through inaccurate and manipulative forecasts by the sales force.

As a result of constant environmental change, fluctuations in customer order volumes, and incorrect estimates of product demand, sales forecasting is a very complex process. Despite these complexities, sales forecasting remains a key determinant of superior planning and resource allocation because it is a key ingredient for managerial decision making (Lynn, Schnaars, \& Skov, 1999; Rieg, 2010). Indeed, executives and managers rely on sales forecasts to make decisions that define strategic alternatives and how resources are allocated in the organization (Lynn, Schnaars, \& Skov, 1999). Because of this, firms that forecast more accurately can deploy resources more efficiently.

But sales forecasts are frequently wrong. Simpson (2000) reported that $59 \%$ of procurement respondents believed that sales forecasts were only somewhat accurate. Because forecasts are relied upon as if they are accurate and are reference points for managerial decision-making (Lynn et al., 1999), imprecise forecasts cause firms to absorb superfluous carrying costs and/or liquidate excess inventory when consumer product demand subsides. In the latter case, companies may be required to take actions such as selling excess inventory below cost or disassembling manufactured products and reselling the standardized parts. Each of these scenarios could result in considerable financial cost. Thus, firms must take care not to overstate sales forecasts since they result in higher overall costs, which could put the firm at a disadvantage vis-à-vis competitors (Porter, 1980).

Sales forecasts are influenced in several ways, yet the factors impacting accuracy can be divided into three main components: (1) dynamic external, (2) dynamic internal, and (3) manipulative internal factors. Dynamic external factors generate forecast errors caused by exogenous factors, such as environmental scanning deficiencies, macroeconomic disruptions, technological discontinuities, as well as other factors (Hambrick \& Mason, 1984). Not unlike the dynamic external factors that impact forecasting accuracy, there is also a dynamic component to internal forecasting error. Weaknesses in forecasting planning (e.g., incorrect trend analysis), human error, and other related factors generate internal forecasting errors. McCarthy, Davis, Golicic and Mentzer (2006) found that more than 
two-thirds of survey respondents reported an absence of accountability for forecast accuracy. Dynamic external and internal forecasting errors are eminent given the unpredictability of organizational and competitive environments. The focus of our paper, however, is on manipulative internal factors, which are factors that make inaccurate forecasts avoidable.

Specifically, inaccurate forecasts might result from how sales compensation systems are setup because such systems appear to create goal incongruence between managers and the sales force. Agency theory (Jensen \& Meckling, 1976) may explain why this incongruence develops, and what managers can do to 'close the gap.' In its classical form, agency theory models the relationship between one who assigns responsibilities (the principal) and one who fulfils them (the agent, which in this case is the sales person). Conflict or goal incongruence arises from the contract that governs this relationship. Recognizing that organizations are fraught with divergent interests, the goal of agency theory is to establish optimal compensation contracts between principals and agents to induce agents to act in principals' interests (Bloom \& Milkovich, 1998).

Although most agency theory research has focused on top executive compensation (e.g., Nyberg, Fulmer, Gerhart, \& Carpenter, 2010; Pepper \& Gore, 2012; Rajgopal, Shevlin, \& Zamora, 2006), we believe that the underlying problem is also evident in the relationship between management and salespeople. Sales compensation systems historically been designed to reward individuals for their direct contributions to firm revenues via commissions on sales. Such systems place compensation risk solely on the salesperson. However, by utilizing such systems, organizations may be writing a prescription for excessive inventory due to manipulative sales forecasts. Specifically, as compensation risk is inherently transferred to the salesperson in a commission-based structure (instead of a salary-based structure), an unintended consequence might be that sales forecasts are manipulated to transfer other forms of risk back to the principal.

Our paper has two overarching objectives. Our first objective is to investigate the unintended consequences of sales compensation structures. The second objective is to provide some prescriptions that might help reduce the financial impact of those unintended consequences. The paper proceeds as follows. The next section provides a brief overview of agency theory. Then we develop propositions. Finally, we discuss the implications of our propositions and what firms can do to remediate the problems associated with the sales commission compensation structure.

\subsection{Agency theory}

Agency theory posits that when principals (owners) delegate tasks to agents (e.g., salespeople), agency problems surface because of goal incongruence and risk preference differences between parties (Eisenhardt, 1989; Jensen \& Meckling, 1976). Agents are assumed to be boundedly rational, risk averse, and self-interested (Eisenhardt, 1989). According to agency theory, principals must ameliorate agency problems through incentive alignment (McGuire, 1988).

Agency conflicts arise within organizations when one party owns less than 100 percent of a firm (Jensen \& Meckling, 1976). In this case, sales representatives (agents) may not have the same level of concern as owners (principals) about the firm's overall profitability because neither profits nor direct inventory costs accrue directly to them. Because variable pay systems such as sales commission compensation systems typically link sales representative pay to sales volume of firm products, sales people are likely most concerned about how much they sell. However, unlike owners, sales representatives are not burdened with inventory costs.

For a sales representative, product availability is critical since they bear the risk of losing all compensation. Not surprisingly, sales compensation books have long warned practitioners that commission sales representatives often manipulate sales orders for their own benefit (Barry, 1981). Thus, variable pay structures are fraught with risk (Stroh et al., 1996). Sales commission compensation structures shift accountability to the sales representative and according to agency theory, this shift may stimulate risk aversion tactics (Eisenhardt, 1989). For example, sales representatives know that if product is not available and/or delivery times are uncertain, customers may seek alternative suppliers, resulting in the loss of a sale, and hence, reduced compensation. Thus, risk averse sales representatives may increase forecasts to ensure adequate inventory levels. Because sales representative compensation is tied to sales revenue and not to inventory costs, commission compensation structure may encourage sales representatives to opportunistically overstate forecasts to ensure product availability. Yet a firm has options to reduce these behaviors. One option to ameliorate this exposure is to invest in monitoring mechanisms, such as information systems, while another is for firms to refine these outcome-based behavioral contracts to reflect the reality of agent opportunism (Demski \& Feltham, 1978). 


\subsection{Consequences of risk preferences}

Sales commission structures are designed to encourage higher sales by linking individual performance to firm performance by rewarding behaviors that increase firm revenues (Banker et al., 1996). The more revenue sales representatives generate, the higher their compensation. Unfortunately however, these commission compensation systems can often promote sales without regard for the associated costs (Lopez, Hopkins, \& Raymond, 2006). Although managers hope that commissions/outcome-oriented contracts provide incentives (Eisenhardt, 1989), commissions can also result in undesirable negative consequences. Thus, there is a cost to this incentive system in the form of potentially higher inventory carrying costs and the expense of liquidating excess inventory below cost.

Due to the risk imposed by outcome-based variable pay contracts (such as commissions) and the risk averse nature of most individuals (Eisenhardt, 1988), sales commission compensation structures can encourage purposeful manipulative behavior (Stroh et al., 1996) that may drive excessive sales forecasts, resulting in diminished organizational efficiency and performance. Although one may think it would be easy to change this reward system to realign these competing interests, this task may be extremely difficult. Sales commissions as a form of compensation have become institutionalized, therefore organizations that attempt to redefine how representatives are compensated would likely face resistance. In addition, firms employing radical compensation re-designs run the risk of losing top sales people to other firms offering more traditional commission compensation systems. Such sales force moves may serve to exacerbate a firm's problems; since the firm's best sales representatives often are also the most likely to find comparable or better employment opportunities in the marketplace.

Figure 1 depicts how risk preferences, incentives, and psychological factors can impact corporate performance through manipulative forecast error. Thus, lower inventory turnover, higher inventory carrying costs, and inventory reduction actions (i.e., sales incentives) may contribute to lower firm performance.

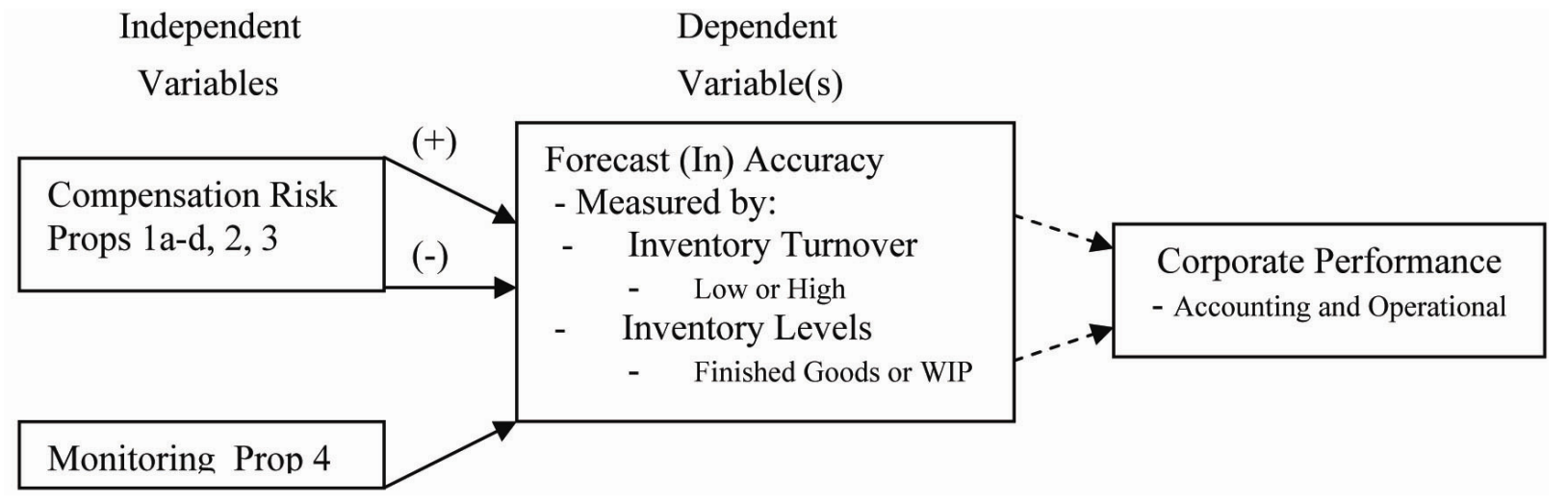

Figure 1. Forecast Accuracy Drivers

\section{Propositions}

\subsection{Compensation effects}

Sales forecasts are often derived through environmental assessments and rely heavily on sales representative input (Ehrman \& Shugan, 1995). Several factors are proposed to influence why sales representatives purposefully manipulate and overstate forecasts (e.g., Ryckman \& Head, 1993); however our propositions begin by investigating how this employee group is compensated. As noted earlier, sales representatives are commonly paid based on a large portion of their compensation upon sales revenue, through the payment of commissions based upon total sales revenue (Barry, 1981; Lal \& Srinivasan, 1993). While this compensation is designed to encourage more sales, it may produce unintended consequences. Agency theory assumes that when given the choice, agents (sales representatives) will act in their own best interest and not the company's (Jensen \& Meckling, 1976). Furthermore, commission based incentive systems require strong oversight to prevent exploitation resulting from order manipulation and overselling (Ryckman \& Head, 1993).

Commissions are commonly used in high risk conditions (Stroh et al., 1996), where commission-based compensation structures represent personal risk measures and are essentially outcome-based contracts between the firm and the sales representative. This individual risk may be diametrically opposed to accurate inventory management and operational excellence. In the sales representatives' case, the notion of driving product forecasts conforms to the notion of risk aversion (Eisenhardt, 1989). As noted earlier, sales representatives will strive to have inventory 
available instead of an empty warehouse. Commission compensation structures can be personal risk measures and likely impact how sales forecasts are derived (Lal \& Srinivasan, 1993). Similarly, managers have been found to make less ethical decisions when their personal welfare is at stake (e.g., Bazerman, Tenbrunsel, \& Wade-Benzoni, 1998; Hoffman, Couch, \& Lamont, 1998). No evidence suggests that sales representatives should be any different. When personal welfare measures such as compensation and bonuses are singularly tied to sales (whether a pure commission level such as $100 \%$ or a graduated scale based upon percentage of quota met) and inventory costs are not, representatives may act in their best interest and intentionally overstate forecasts. Therefore, we propose:

Proposition 1a. In situations where sales force forecasts drive production, sales based commission compensation structures (including bonuses) based on sales revenue will predict excess inventory (i.e., higher inventory levels).

Proposition 1b. Increasing sales representative salary level component (i.e., non-commission) will reduce excess inventory.

Alternatively, firms could use inducements to bring competing interests into equilibrium. Inducements could promote incentive alignment and ultimately reduce manipulative forecast error. Proper incentives can be powerful mechanisms for eliminating agency conflict (Tosi, Werner, Katz, \& Gomez-Mejia, 2000). Moreover, aligning incentives can be accomplished in a variety of ways. One way to accomplish this is to link sales representative bonuses to corporate financial performance. Because representatives will be paying for the inventory (albeit indirectly), this should encourage more concise forecasting and may help bring competing interests into equilibrium, thus:

Proposition 1c. Linking sales representative bonuses to corporate financial performance will reduce manipulative forecast error.

Similarly, sales representative bonuses could also be linked to forecast accuracy. Typically, representatives provide sales reports that give management visibility to projected sales (Davis, \& Mentzer, 2007; Ehrman \& Shugan, 1995). In turn, managers could link incentives to forecast accuracy, thereby making it rational to provide accurate forecasts (Kerr, 1975). Therefore:

Proposition 1d. Linking sales representative compensation to accurate forecasts will reduce excess inventory.

\subsection{Product portfolio effects}

Another potential reason leading sales representatives to overstate forecasts is to grow the available product portfolio (O'Leary-Kelly \& Flores, 2002). This conforms to agency theory's assumption of risk averse and self-interest and may be more prevalent when representatives have few products available for sale or a territory with declining sales revenue. Consider the representative faced with lower sales because of new product introductions by competing firms. However, if representatives provide low new product forecasts, this may cause a firm to cancel a new product introduction (Ehrman \& Shugan, 1995). Thus, promising new product forecasts are often antecedents to new product introductions. In short, there may be times when sales representatives feel that their existing products are inadequate relative to customer needs and competitor offerings. In such cases, the representatives may seek to increase the number of products available in their sales portfolios because their compensation is tied to sales revenue (Ryckman \& Head, 1993). In other words, representatives may purposefully overstate forecasts to entice management to develop more products for their portfolio and speed up the firm product life cycle, when in reality they lack confidence in the sales forecast provided. Thus:

Proposition 2. Sales representatives will increase forecasts for new product introductions if they believe their existing product portfolios are inadequate.

Sales representative compensation can be timed in several ways (Barry, 1981). Not only are sales representatives paid when purchase orders are cut, but they can also be paid when product is shipped to the customer. Naturally, the latter compensation structure places a greater emphasis on product availability. If it takes weeks or months for a product to ship, it can jeopardize the order because customers may go elsewhere. Additionally, this system forces the sales representative to wait patiently for compensation. What happens if the customer is not willing to accept this delay? This problem may be critical because many products have plausible substitutes (Porter, 1980). Given this, long product development and production cycle times may leave representatives feeling vulnerable since their compensation is directly tied to sales revenue. When product is not readily available, customers may go elsewhere if comparable substitutes exist. This is a risk that the organization takes, however it may activate sales representative risk aversion tactics, thus they may act opportunistically and intentionally increase forecasts to ensure product availability (Coughlan \& Sen, 1989). If a representative has to wait months for payment for product sales occurring 
in an earlier time period, the representative may purposefully manipulate forecasts to ensure product availability in order to get paid expeditiously, therefore:

Proposition 3. Organizations that compensate sales representatives when products are shipped will have higher inventory levels than organizations that compensate sales representatives when order is executed.

\subsection{Monitoring effects}

Although there are costs to monitoring (Lenz and Engledow, 1986), this can be an effective method to reduce agent opportunism (Kirby \& Davis, 1998). In the case of forecasting, representatives might exercise more caution if they felt they were being monitored. Agents' decisions will resemble principals' interests when a principal can monitor and verify an agent's actions (Jensen \& Meckling, 1976). One potential monitoring mechanism is a sales audit. Audits are thought to improve accountability (e.g., Moon, Mentzer, \& Thomas, 2000) and thus, sales audits could potentially reduce manipulative forecasts error. Therefore:

Proposition 4. Sales forecast audits will reduce excess inventory.

\section{Discussion}

Drawing on agency theory, we outlined how sales forecasts can be manipulated to decrease the risk transferred as a result of commission-based sales compensation structures. Although we expect risk to play a central role in sales peoples' decisions to purposefully manipulate and overstate forecasts to ensure product availability, it is important to note that because of trends such as scaled commissions (variable sales compensation rates based on sales quota), the opposite scenario might also hold true (Ryckman \& Head, 1993). In such scenarios, employees have been found to "pad their plan" to provide slack in their metrics (Lyles \& Lenz, 1982). For example, sales representatives may argue that they can only sell 100 units so they receive higher bonuses if they sell 200. Such compensation issues illustrate a limitation to studying compensation through a single theory framework.

Another limitation includes distinguishing if forecast manipulation is intentional. In some cases, selective perception may also confound cognitive capacities used to forecast (Dearborn \& Simon, 1958). Similarly, mental capabilities, cognitive strain, short term memory and role ambiguity may also play a role in planning performance (Lyles \& Lenz, 1982). In short, inaccurate forecasts may result from cognitive overload. Thus, forecast variances may rise when the number of products available for sale by each representative increases. More specifically, human limitations may partially moderate, and thus, provide a different explanation to why forecasts are overstated. This opens up a potentially fruitful avenue for future inquiry. Lastly, we suspect that organizational politics play a role in forecasting accuracy. For instance, inter-functional organizational conflict (i.e., animosity) between sales organizations and procurement or production may increase excess inventory (i.e., higher inventory levels). Whereas salespeople want inventory available for sale, procurement and productions staff, whose compensation is likely linked to a different set of performance metrics, might try to hold inventory levels too low. Thus, more research is needed to determine how conflicting interests between the sales force and demand planners, production, and/or procurement influence forecasting accuracy.

\section{Implications for Practice}

We illustrate the prevalence of agency problems in sales force commission systems. Although agency problems have been discussed in many other settings, this theory has received scant attention when examining how compensation risk and psychological variables encourage forecast manipulation within firms. Our hope is that this framework encourages scholars and managers to give equal attention to both the quantitative and qualitative aspects of forecasting because human factors likely play a role (Lyles \& Lenz, 1982). Moreover, there may be other factors to consider, such as the trade off between revenues and costs in certain contexts. Too much inventory can lower profits (via increased costs) while too little inventory (i.e., stock outs) yields lower revenues. Thus, organizational objectives, whether revenue growth, profitability, or some composite thereof, must be considered when dissecting these issues because some organizations may be willing to carry higher inventory levels in exchange for potentially higher revenues.

Taking these issues into account, it appears as if there is a strong need to modify sales commission compensation systems. Nevertheless, changing such systems might be difficult since commission structures have become institutionalized as rational incentives to increase sales within firms. Indeed, Lopez et al. (2006) demonstrate that increases in commission rates are preferred by salespeople over other rewards, including pay raises, promotion, and recognition. Moreover, the level and design of the sales compensation structure impact the quality of salespeople a company can attract (Brown et. al, 2005). Thus, inertial forces (Hannan \& Freeman, 1977) will likely subdue any significant modification to this widely-used compensation structure. However, there are other approaches to 
potentially increase forecast accuracy through incremental compensation structure enhancements, which in turn, can increase organizational performance. For example, organizations can modify sales representative compensation structures and link them more closely with corporate financial performance. Or, organizations may include forecasting accuracy as a part of sales representative bonuses computation. If organizations find these compensation adjustments limiting, there are other alternatives that can potentially increase forecast accuracy. Firms often use a portfolio of incentives and monitoring instruments to offset the limitations of using single incentives (Pendleton, 2006).

Despite the potential advantages of linking sales representative compensation to forecast accuracy, there is a need for other viable options. Since monitoring has been found to be an effective tool in other contexts (Conlon \& McLean Parks, 1990), implementing sales audits might improve forecast accuracy. Alternatively, getting customers involved in the product development process may help provide visibility to sales forecasts, thereby increasing accuracy and reducing the probability of carrying excess inventory. Another potential option for reducing forecast error is for organizations to create cultural mechanisms that focus on balancing competing interests and increased communication within firms, especially since such factors contribute to forecasting error as the behavior and performance of salespeople (Simintiras, Lancaster, \& Cadogan, 1994).

\section{Conclusion}

In conclusion, this paper provides some insight into why planning efforts in the form of forecasting may not always lead to superior organizational performance. From the agency theory perspective, we outline how sales compensations systems can inadvertently cause excessive inventory expenses as a result of self-serving product forecasts by salespeople. Additional research should be conducted to facilitate scholarly progress in this area and to define improved process and outcome controls. Perhaps these future explorations will help elucidate the role of forecasting accuracy in firm performance and further attend to Ramanujam and Venkatraman's (1987) question "what characteristics of a planning system are critical for planning effectiveness."

\section{References}

Ackoff, R. (1967). Management misinformation systems. Management Science, 14, 147-156. http://dx.doi.org/10.1108\%2Feb000823

Armstrong, J. (1982). The value of formal planning for strategic decisions: Reviews of empirical research. Strategic Management Journal, 3, 197-211. http://dx.doi.org/10.1002\%2Fsmj.4250030303

Banker, R., Lee, S. Y., Potter, G., \& Srinivasan, D. (1996). Contextual analysis of performance impacts of outcome-based incentive compensation. Academy of Management Journal, 39, 920-948. http://dx.doi.org/10.2307\%2F256717

Barry, J. (1981). Effective Sales Incentive Compensation. New York, NY: McGraw-Hill Inc.

Basu, A. K., Lal, R., Srinivasan, V., \& Staelin, R. (1985). Salesforce compensation plans: An agency theoretic perspective. Marketing Science, 4, 267-291. http://dx.doi.org/10.1287\%2Fmksc.4.4.267

Bazerman, M., Tenbrunsel, A., \& Wade-Benzoni, K. (1998). Negotiating with yourself and losing: Making decisions with competing internal preferences. Academy of Management Review, 23, 225-241. http://dx.doi.org/10.2307\%2F259372

Bloom, M., \& Milkovich, G.T. (1998). Relations among risk, incentive pay, and organizational performance. Academy of Management Journal, 41, 283-297. http://dx.doi.org/10.2307/256908

Bobocel, D., \& Meyer, J. (1994). Escalating commitment to a failing course of action--separating the roles of choice $\begin{array}{lllll}\text { and justification. Journal of Applied } & \text { Psychology, } & \text { 79, }\end{array}$ http://dx.doi.org/10.1037\%2F\%2F0021-9010.79.3.360

Boettger, R., \& Greer, C. (1994). On the wisdom of rewarding A while hoping for B. Organization Science, 5, 569-582. http://dx.doi.org/10.1287\%2Forsc.5.4.569

Boulding, W., Morgan, R., \& Staelin, R. (1997). Pulling the plug to stop the new product drain. Journal of Marketing Research, 34, 164-176. http://dx.doi.org/10.2307\%2F3152073

Bowman, E., \& Helfat, C. (2001). Does corporate strategy matter? Strategic Management Journal, 22, 1-23. http://dx.doi.org/10.1002\%2F1097-0266\%28200101\%2922\%3A1\%3C1\%3A\%3AAID-SMJ143\%3E3.3.CO\%3 B2-K 
Brockner, J. (1992). The escalation of commitment to a failing course of action: Toward theoretical progress. Academy of Management Review, 17, 39-61. http://dx.doi.org/10.5465/AMR.1992.4279568

Brown, S. P., Evans, K. R., Mantrala, M.K., \& Challagalla, G. (2005). Adapting motivation, control, and compensation research to a new environment. Journal of Personal Selling \& Sales Management, 25, 156-167.

Chen, F. (2005). Salesforce incentives, market information, and production/inventory planning. Management Science, 51, 60-75. http://dx.doi.org/10.1287/mnsc. 1040.0217

Chen, F. (2000). Sales-force incentives and inventory management. Manufacturing \& Service Operations Management, 2, 186-202. http://dx.doi.org/10.1287/msom.2.2.186.12351

Conlon, E., \& McLean Parks, J. (1990). Effects of monitoring and tradition on compensation arrangements: An experiment with principal-agents dyads. Academy of Management Journal, 33, 603-622. http://dx.doi.org/10.2307/256583

Coughlan, A. T., \& Narasimhan, C. (1992). An empirical analysis of sales-force compensation plans. Journal of Business, 65, 93-121. http://dx.doi.org/10.1086/296559

Coughlan, A., \& Sen, S. (1989). Salesforce compensation: Theory and managerial implications. Marketing Science, 8, 324-342. http://dx.doi.org/10.1287/mksc.8.4.324

Davis, D. F., \& Mentzer, J. T. (2007). Organizational factors in sales forecasting management. International Journal of Forecasting, 23, 475-495. http://dx.doi.org/10.1016/j.ijforecast.2007.02.005

Dearborn, D., \& Simon, H. (1958). Selective perception: A note on the department identifications of executives. Sociometry, 21, 140-144. http://dx.doi.org/10.2307/2785898

Demski, J. S. \& Feltham, G. (1978). Economic incentives in budgetary control systems. Accounting Review, 53, 336-359.

Dutton, J., \& Duncan, R. (1987). The creation of momentum for change through the process of strategic issue diagnosis. Strategic Management Journal, 8, 279-295. http://dx.doi.org/10.1002/smj.4250080306

Eisenhardt, K. (1988). Agency-and institutional-theory explanations: The case of retail sales compensation. Academy of Management Journal, 31, 488-511. http://dx.doi.org/10.2307/256457

Eisenhardt, K. (1989). Agency theory: An assessment and review. Academy of Management Review, 14, 57-74. http://dx.doi.org/10.2307/258191

Ehrman, C., \& Shugan, S. (1995). The forecaster's dilemma. Marketing Science, 14, 123-147. http://dx.doi.org/10.1287/mksc.14.2.123

Hambrick, D., \& Mason, P. (1984). Upper echelons: The organization as a reflection of its top managers. Academy of Management Review, 9, 193-206. http://dx.doi.org/10.2307/258434

Hannan, M., \& Freeman, J. (1977). The population ecology of organizations. American Journal of Sociology, 82, 929-964. http://dx.doi.org/10.1086/226424

Hoffman, J., Couch, G., \& Lamont, B. (1998). The effect of firm profit versus economic well being on the level of ethical responses given by managers. Journal of Business Ethics, 17, 239-244.

Jensen, M., \& Meckling, W. (1976). Theory of the firm: Managerial behavior, agency costs, and ownership structure. Journal of Financial Economics, 3, 305-360.

Joseph, K., \& Thevaranjan, A. (1998). Monitoring and incentives in sales organizations. Marketing Science, 17, 107-123. http://dx.doi.org/10.1287/mksc.17.2.107

Kahneman, D., \& Tversky, A. (1979). Prospect theory: An analysis of decisions under risk. Econometrica, 47, 263-291. http://dx.doi.org/10.2307/1914185

Kerr, S. (1975). On the folly of rewarding A, while hoping for B. Academy of Management Journal, 18, 769-783. http://dx.doi.org/10.2307/255378

Kirby, S., \& Davis, M. (1998). A study of escalating commitment in principal-agent relationships: Effects of monitoring and personal responsibility. Journal of Applied Psychology, 83, 206-217. http://dx.doi.org/10.1037//0021-9010.83.2.206 
Krafft, M., Albers, S., \& Lal, R. (2004). Relative explanatory power of agency theory and transaction cost analysis in German sales forces. International Journal of Research in Marketing, 21, 265-283. http://dx.doi.org/10.1016/j.ijresmar.2003.11.001

Kudla, R. (1980). The effects of strategic planning on common stock returns. Academy of Management Journal, 23, 5-20. http://dx.doi.org/10.2307/255493

Lal, R., \& Srinivasan, V. (1993). Compensation plans for single- and multi-product saleforces: An application of the Holmstrom-Milgrom model. Management Science, 39, 777-793. http://dx.doi.org/10.1287/mnsc.39.7.777

Lenz, R., \& Engledow, J. (1986). Environmental analysis units and strategic decision making: A field study of selected 'leading edge' companies. Strategic Management Journal, 7, 69-89. http://dx.doi.org/10.1002/smj.4250070107

Libby, R., \& Fishburn, P. (1977). Behavioral models of risk taking in business decisions: A survey and evaluation. Journal of Accounting Research, 15, 272-292. http://dx.doi.org/10.2307/2490353

Lopez, T. B., Hopkins, C. D., \& Raymond, M. A. (2006). Reward preferences of salespeople: How do commissions rate? Journal of Personal Selling \& Sales Management, 26, 381-390. http://dx.doi.org/10.2753/PSS0885-3134260405

Lynn, G., Schnaars, S., \& Skov, R. (1999). Survey of new product forecasting practices in industrial high technology and low technology business. Industrial Marketing Management, $28, \quad 565-571$. http://dx.doi.org/10.1016/S0019-8501(98)00027-3

Lyles, M., \& Lenz, R. (1982). Managing the planning process: A field study of the human side of planning. Strategic Management Journal, 3, 105-118. http://dx.doi.org/10.1002/smj.4250030203

Mantrala, M. K., \& Raman, K. (1990). Analysis of a sales force incentive plan for accurate sales forecasting and performance. International Journal of Research in Marketing, 7, 189-202. http://dx.doi.org/10.1016/0167-8116(90)90021-E

March, J., \& Shapira, Z. (1987). Managerial perspectives on risk and risk taking. Management Science, 33, 1404-1418. http://dx.doi.org/10.1287/mnsc.33.11.1404

McCarthy, T. M., Davis, D. F., Golicic, S. L., \& Mentzer, J. T. (2006). The evolution of sales forecasting management: A 20-year longitudinal study of forecasting practices. Journal of Forecasting, 25, 303-324. http://dx.doi.org/10.1002/for.989

McGuire, J. (1988). Agency theory and organizational analysis. Managerial Finance, 14, 6-9. http://dx.doi.org/10.1108/eb013601

Mishra, S., Coughlan, A. T., \& Narasimhan, C. (2005). Salesforce compensation: An analytical and empirical examination of the agency theoretic approach. Quantitative Marketing and Economics, 3, 5-39. http://dx.doi.org/10.1007/s11129-005-0164-2

Moon, M., Mentzer, J., \& Thomas Jr., D. (2000). Customer demand planning at Lucent Technology. Industrial Marketing Management, 29, 19-26. http://dx.doi.org/10.1016/S0019-8501(99)00108-X

Nyberg, A. J., Fulmer, I. S., Gerhart, B., \& Carpenter, M. A. (2010). Agency theory revisited: CEO return and shareholder interest alignment. Academy of Management Journal, 53, 1029-1049. http://dx.doi.org/10.5465/AMJ.2010.54533188

O'Leary-Kelly, W., \& Flores, B. (2002). The integration of manufacturing and marketing/sales decisions: Impact on organizational performance. Journal of Operations Management, 20, 221-240. http://dx.doi.org/10.1016/S0272-6963(02)00005-0

Pendleton, A. (2006). Incentives, monitoring, and employee stock ownership plans: New evidence and interpretations. Industrial Relations, 45, 753-777. http://dx.doi.org/10.1111/j.1468-232X.2006.00450.x

Pepper, A., \& Gore, J. (2012). Behavioral agency theory: New foundations for theorizing about executive compensation. Journal of Management, 20, 1-24.

Porter, M. E. (1980). Competitive Strategy, New York, NY: The Free Press.

Porteus, E., \& Whang, S. (1991). On manufacturing/marketing incentives. Management Science, 37, 1166-1181. http://dx.doi.org/10.1287/mnsc.37.9.1166 
Rajgopal, S., Shevlin, T., \& Zamora, V. (2006). CEOs' outside employment opportunities and the lack of relative performance evaluation in compensation contracts. Journal of Finance, 61, 1813-1844.

Ramanujam, V., \& Venkatraman, N. (1987). Planning system characteristics and planning effectiveness. Strategic Management Journal, 8, 453-468. http://dx.doi.org/10.1002/smj.4250080505

Rieg, R. (2010). Do forecasts improve over time?: A case study of the accuracy of sales forecasting at a German car manufacturer. International Journal of Accounting and Information Management, 18, 220-236. http://dx.doi.org/10.1108/18347641011068974

Ryckman, W., \& Head, R. (1993). Compensating your sales force. Chicago, IL: Probus Publishing Company.

Sharp, D., \& Salter, S. (1997). Project escalation and sunk costs: A test of the international generalizability of agency and prospect theories. Journal of International Business Studies, 28, 101-121. http://dx.doi.org/10.1057/palgrave.jibs.8490095

Simintiras, A. C., Lancaster, G. A., \& Cadogan, J. W. (1994). Perceptions and attitudes of salespeople towards the overall sales job and the work itself: Some preliminary findings. Journal of Managerial Psychology, 9, 3-10. http://dx.doi.org/10.1108/02683949410075822

Simpson, P. (2000). Sales forecasting management. [Review of the book Sales forecasting management], Journal of the Academy of Marketing Science, 28, 547-548.

Sitkin, S., \& Pablo, A. (1992). Reconceptualizing the determinants of risk behavior. Academy of Management Review, 17, 9-38. http://dx.doi.org/10.2307/258646

Staw, B. (1981). The escalation of commitment to a course of action. Academy of Management Review, 6, 577-587. http://dx.doi.org/10.2307/257636

Staw, B., \& Barsade, S. (1993). Affect and managerial performance: A test of the sadder-but-wiser vs. happier-but-smarter hypotheses. Administrative Science Quarterly, 38, 304-331. http://dx.doi.org/10.2307/2393415

Stroh, L, Brett, J., Baumann, J., \& Reilly, A. (1996). Agency theory and variable pay compensation strategies. Academy of Management Journal, 39, 751-767. http://dx.doi.org/10.2307/256663

Tosi, H. L., Werner, S., Katz, J. P., \& Gomez-Mejia, L. R. (2000). How much does performance matter? A meta-analysis of CEO pay studies", Journal of Management, 26, 301-339. http://dx.doi.org/10.1016/S0149-2063(99)00047-1

Whyte, G. (1986). Escalating commitment to a course of action: A reinterpretation. Academy of Management Review, 11, 311-321. http://dx.doi.org/10.2307/258462

Wickramasinghe, N. (2006). Expanding the explanatory power of agency theory for the knowledge economy. International Journal of Management and Enterprise Development, 3, 510-520. http://dx.doi.org/10.1504/IJMED.2006.009573 